\title{
КТО УБИЛ SPITZENKANDIDAT?
}

Аннотация. В статье анализируется процесс номинирования и избрания нового Председателя Комиссии ЕС, а также других руководителей Евросоюза. Опираясь на результаты внеочередного саммита ЕС 30 июня - 1 июля 2019 г., который «похоронил» систему Spitzen-kandidaten, а также и дебаты в Европарламенте, автор делает вывод о причастности к провалу практики вылвижения ведущего кандидата не только глав государств и правительств, но и европейских политических партий, а также депутатов Европарламента.

Ключевые слова: ведущий кандидат, саммит, Европейский совет, Комиссия, Европейский парламент, выборы, транснациональные списки, Европейская народная партия, Партия европейских социалистов, пакет Осаки.

Изменение процедуры избрания главы Комиссии ЕС стало центральной темой дебатов в Европейском совете и в Европарламенте задолго до европейских выборов. Главы государств и правительств на саммите в феврале 2018 г. выразили сомнения относительно автоматического назначения Spitzenkandidat (ведущего кандидата) от европейской политической партии, которая покажет лучший результат на предстоявших выборах в Европарламент. В свою очередь, евродепутаты крайне неодобрительно отнеслись к заключениям саммита и постоянно уверяли, что поддержат только кандидатуру ведущего кандидата на пост Председателя Ко-миссии ${ }^{1}$.

В идеале в результате выборов в Европарламент в мае 2019 г. Комиссию должен был возглавить Манфред Вебер - Spitzenkandidat от Европейской народной партии (ЕНП). Следующим претендентом стал бы Франц Тиммерманс, ведущий кандидат от Партии европейских социалистов (ПЕС), показавшей второй результат. Напомним, что при аналогичном раскладе пять лет назад один ведущий кандидат - Жан-Клод Юнкер, выдвинутый ЕНП, возглавил Комиссию, второй - Мартин Шульц от ПЕС, стал Председателем Европарламента, процедура же утверждения руководителей Евросоюза прошла гладко. В 2019 г. мало кто надеялся, что сценарий повторится. Лидеры ЕС серьёзно опасались прогнозируемого успеха популистских партий. Однако фактор евроскептиков не сыграл заметной роли при номинировании на пост главы Еврокомиссии, которое должно было произойти на внеочередном саммите ЕС 30 июня - 2 июля 2019 г.

\section{Провал «пакета Осаки»}

К утру 1 июля после 20 часов изнурительных переговоров главы государств и правительств вынуждены были признать, что им не удалось достигнуть политического

(С Потемкина Ольга Юрьевна - доктор политических наук, главный научный сотрудник, руководитель Отдела исследований европейской интеграции Института Европы РАН. Aдрес: 125009, Россия, Москва, ул. Моховая, д. 11, стр. 3.E-mail: olga_potemkina@mail.ru.

DOI: http://dx.doi.org/10.15211/vestnikieran420193237

${ }^{1}$ Потемкина О.Ю. Европейский парламент 2019: подготовка к выборам. Современная Европа, №4, 2018. С. $35-$ 46. 
баланса по вопросу назначений на руководящие посты в Евросоюзе. Для продолжения дискуссии решено было встретиться 2 июля после короткой передышки. Она особенно нужна была лидерам ряда стран Евросоюза, которые участвовали во встрече Группы 20 и прибыли в Брюссель пря-мо из Осаки, где также обсуждали предстоявшую номинацию.

«Пакет Осака», разработанный незадолго до саммита Группы 20, предлагался главам государств-членов на встрече в Брюсселе в различных комбинациях, но неизменно с включением Франца Тиммерманса, ведущего кандидата от Партии европейских социалистов (ПЕС) на посту главы Комиссии. При этом Тиммерманс мог рассчитывать и на безусловную поддержку Европарламента. Пост будущего Председателя Евросовета предполагалось отдать кандидату от либералов; политическая семья христианских демократов претендовала на посты Председателя Европарламента, где желала видеть ведущего кандидата от Европейской народной партии (ЕНП) Манфреда Вебера, а также и Высокого представителя по иностранным делам и политике безопасности. Председательство в Европейском центральном банке планировалось отдать Франции, в связи с этим упоминалось сразу имя Кристин Лагард, дей-ствовавшей главы Международного валютного фонда. Отметим, что главы государств-членов не обсуждали «пакет Осака» с действующим председателем Евросовета Дональдом Туском, который был недоволен нарушением гендерного и географического принципов при распреде-лении руководящих постов.

Против пакета выступили и несколько лидеров стран ЕС, не участвовавшие в заседании Группы 20. «Во время предыдущего саммита Евросовета было решено, что принцип “ведущего кандидата" не может быть правильным решением, поэтому мы отказались от него», заявил премьер-министр Италии Джузеппе Конте. Как и Туск, Конте осудил сам метод составления пакета назначений, который обсуждался вне Евросовета.

Оппозицию в самой ЕНП возглавил премьер-министр Ирландии Лео Варадкар, который раскритиковал «головоломку», придуманную в Осаке. По его мнению, христианские демократы не должны были отдавать пост Председателя Комиссии так легко, ведь они получили большинство голосов по итогам выборов в Европарламент. Кандидатуру Тиммерманса реши-тельно отвергли страны Вишеградской группы. В открытом письме к председателю ЕНП пре-мьер-министр Венгрии Виктор Орбан назвал такую номинацию «исторической ошибкой». Позиция вишеградцев стала местью Тиммермансу, который вёл переговоры от лица Комиссии с Польшей и с Венгрией, обвиняемыми в нарушении верховенства закона.

Посетовав на «плохой результат» саммита, канцлер Германии Ангела Меркель пояснила, что перерыв в переговорах нужен был, чтобы избежать нагнетания напряженности на не-сколько следующих лет, тем более на фоне брекзита. Президент Франции Эммануэль Макрон счёл необходимым разобраться в причинах провала саммита, «авторитет которого подорван чрезмерно длинными заседаниями, которые в итоге ни к чему не привели», он отметил и пер-сональные амбиции некоторых лидеров, которые никак не способствовали решению вопроса. Макрон выразил надежду, что новых кандидатов уже никто «не вытащит из шляпы» ${ }^{1}$.

Однако президент Франции ошибся, новые имена появились в течение третьего дня чрезвычайного саммита, 2 июля, когда главы государств и правительств пришли, наконец, к консенсусу по вопросу ключевых назначений в Евросоюзе. На пост председателя Комиссии ЕС была впервые в истории ЕС номинирована дама - Урсула фон дер Ляйен, министр обороны Германии и член германского ХДС. Саммит выбрал Шарля Мишеля, премьер-министра

\footnotetext{
${ }^{1}$ Europe Daily Bulletin. №12286. 2 July 2019. P. 3.
}

Научно-аналитический вестник ИЕ РАН, 2019, №4 
Бельгии в отставке, центриста из европейского «Альянса либералов и демократов» Председателем Европейского совета на срок 2,5 лет (с 1 декабря 2019 г. по 31 мая 2022 г.); на должность Высокого представителя по иностранным делам и политике безопасности был выдвинут социалист Жозеф Борелл, а социалист Давид Сассоли 3 июля был избран Председателем Европарламента. Лишь имя Кристин Лагард совпало с предложением «пакета Осака».

Канцлер Меркель поддержала назначение фон дер Ляйен (несмотря на то, что ранее выступала за тандем «Тиммерманс-Вебер») и отметила опыт германского министра обороны в вопросах миграции, миссиях НАТО, а также приверженность в целом Европейскому союзу. Для президента Франции согласие, к которому пришли участники саммита, стало «результатом глубокого франко-германского взаимопонимания», уважением критериев компетентности и опыта. Макрон выразил удовлетворение «глубоким обновлением», которое отражает «новый баланс» сил в результате выборов в Европарламент ${ }^{1}$, имея в виду, повидимому смену тандема ЕНП-ПЕС при номинировании главы Еврокомиссии на новый, франко-германский.

Донадьд Туск на этот раз был удовлетворён гендерным принципом распределения ключевых ролей, что, по его мнению, облегчит прохождение кандидатур через Европарламент, но никак не географическим, и выразил надежду, что хотя бы вице-председателями Комиссии станут политики из стран Центральной и Восточной Европы и Италии 2 .

Таким образом, Европейский совет похоронил процесс Spitzenkandidaten: оба «ведущих кандидата» от европейских партий - Манфред Вебер (ЕНП) и Франц Тиммерманс (ПЕС) не смогли получить номинацию на пост главы Комиссии. Последним сдался премьер-министр Испании Педро Санчес, за его отказ от поддержки тандема Испания получила должность Высокого представителя, на которую перед эти прочили Мароша Шефчовича, хорошо зарекомендовавшего себя в составе прежней Комиссии.

\section{Коллективная ответственность за убийство}

«Мы верили, что сработает принцип ведущего кандидата, но этого не произошло», посетовал новый председатель Европарламента Давид Сассоли после того, как лидеры государств-членов проигнорировали предпочтения евродепутатов на руководящие посты в EC. Многочасовой политический марафон глав государств и правительств поставил точку в чере-де саммитов, в ходе которых обсуждалась судьба системы ведущего кандидата. Кто виноват в его гибели? Манфред Вебер, главный несостоявшийся Spitzenkandidat, прямо указал на союз президента Франции Макрона и премьер-министра Венгрии Орбана.

Появившийся относительно недавно на политической арене Макрон не принадлежит ни к одной из европейских политических семей, он никогда не скрывал своего неприятия системы ведущего кандидата, поскольку не видел никаких преимуществ для себя и своей центристской политической группы. Последним аргументом президента было то, что нынешние ведущие кандидаты были неизвестны европейским избирателям. К тому же Макрон отметил недостаточную профессиональную подготовку Вебера для столь важной должности, на которую ранее избирали гораздо более весомых политиков. Одновре́менно французский президент попытался извлечь выгоду из сложившейся ситуации, вернувшись к своей старой идее, которая пока не нашла поддержки у коллег по Евросоюзу - чтобы принцип Spitzenkandidaten

\footnotetext{
${ }^{1}$ Europe Daily Bulletin. №12287, 3 July 2019.

${ }^{2}$ Conclusions du Conseil européen, 30 juin - 2 juillet 2019. URL: https://www.consilium.europa.eu/fr/press/pressreleases/2019/07/02/european-council-conclusions-30-june-2-july-2019/ (дата обращения: 05.07.2019).
} Научно-аналитический вестник ИЕ РАН, 2019, №4 
сработал, необходимо ввести транснациональные списки депутатов, тогда избиратели всего Евросоюза получат возможность голосовать не только за национальных, но и за других европейских лидеров и политические партии. Гораздо лояльнее он отнёсся к кандидату от социалистов и демократов Францу Тиммермансу, но премьер-министр Венгрии Орбан приложил руку к уничтожению сразу двух ведущих кандидатов - Вебера и Тиммерманса, быстро переметнувшись в лагерь противников данного принципа. Ещё в марте Орбан обещал поддерживать Манфреда Вебера до конца, но передумал, после того, как Германия выступила за приостановление членства партии Орбана ФИДЕС в ЕНП.

Отвергая обвинения Вебера, французские политики предложили ему обратить внимание на себя и на родную Европейскую народную партию. Ни Орбан в одиночку, ни вместе с остальными странами Вишеградской группы не смог бы провалить ведущих кандидатов. В случае с Вебером ему помог Макрон, а с Тиммемансом - национальные лидеры, входящие в ЕНП, во главе с премьер-министром Ирландии Лео Варадкаром. Они не приняли компромиссного плана Меркель, которая надеялась разделить ключевые посты между двумя ведущими кандидатами - Тиммермансу отдать пост главы Комиссии, а Веберу - Председателя Парламента. Но евродепутаты предпочли пожертвовать системой Spitzenkandidaten, чтобы сохранить за ЕНП руководство Комиссией. В этом глав государств и правительств поддержали депутаты Европарламента от ЕНП. Когда к утру 1 июля после ночных дебатов некоторые участники саммита всё ещё пытались продвинуть Тиммерманса, из Страсбурга пришло сообщение, что ЕНП не проголосует ни за одного кандидата, не принадлежащего к христианским демократам и консерваторам. Что касается самого Вебера, то будучи ведущим кандидатом от партии, показав-шей лучший результат на выборах в Европарламент, он, тем не менее, не смог заручиться поддержкой других проевропейских фракций, с помощью которой он мог бы противостоять выбору глав государств и правительств. Не удалось Веберу уговорить коллег по парламентской группе согласиться на компромиссный план Меркель, который помог бы сохранить систему ведущего кандидата ${ }^{1}$.

Депутаты Европарламента обвинили всех глав государств и правительств, которые отказались от ведущего кандидата в пользу номинации Урсулы фон дер Ляйен. Многие политики и эксперты также ставят в вину Европарламенту то, что он не защищал должным образом систему назначения главы Комиссии, если она была ему так дорога. Не только Вебер, но и Тиммерманс, а также и Маргрет Вестагер - ведущий кандидат от либералов не смогли бы пройти утверждение в Европарламенте. Евродепутаты не захотели пойти на компромисс для поддержки принципа, который они так долго отстаивали, что дало возможность саммиту выдвинуть неожиданную кандидатуру - Урсулу фон дер Ляйен.

Таким образом, в убийстве Spitzenkandidaten поучаствовали все лидеры и европейские партии, но по разным причинам. Уходящий председатель Комиссии Ж.-К. Юнкер во время пресс-конференции в Хельсинки 5 июля констатировал, что процесс номинация его преемницы Урсулы фон дер Ляйен и других руководителей ЕС был «не очень прозрачным». «Я в любом случае войду в историю... я уникальный человек, потому что я первый и последний Spit-zenkandidat», - грустно пошутил Юнкер².

Возможно, он ошибся. Не только президент Франции Макрон, но и канцлер Германии Меркель оставили для себя возможность вернуться к принципу ведущего кандидата.

\footnotetext{
${ }^{1}$ Gray A., Barigazzi J., De La Baume M. Who killed the Spitzenkandidat? Politico. 07.07.2019. URL: https://www.po litico.eu/article/who-killed-the-spitzenkandidat-european-parliament-election-2019-transition/ (дата обращения: 07.07. 2019).

${ }^{2}$ Europe Daily Bulletin №12290, 6 July 2019. P. 6.
}

Научно-аналитический вестник ИЕ РАН, 2019, №4 
«Больше не должно случиться, чтобы Spitzenkandidaten не прошёл номинирования... Нам следует усовершенствовать данную практику», сказала она, имея в виду «транснациональные списки избирателей» и выборы Председателя Комиссии прямым всеобщим голосованием. А вновь избранный председатель Европарламента Давид Сассоли пошёл ещё дальше - он предложил собрать межправительственную конференцию для обсуждения возможных изменений в процессе назначений на руководящие посты в Евросоюзе ${ }^{1}$.

\section{Европейский парламент: утверждение на грани срыва}

Тем временем номинированная глава Комиссии готовилась предстать перед Европейским парламентом, который ранее неоднократно заявлял, что поддержит только ведущего кандидата. Германские социал-демократы, группа социалистов и демократов в Европарламен-те, а также и «Зелёные - Европейский свободный альянс» не скрывали своего раздражения новым назначением, поэтому до самого голосования не было понятно, проглотят ли евродепутаты горькую пилюлю.

Надо отдать должное У. фон дер Ляйен, она провела очень интенсивную неделю письменных обращений и встреч и с различными политическими группами депутатов, стремясь продемонстрировать содержательность и полезность своей программы, в которой попыталась охватить широкий круг вопросов - от изменений климата до занятости молодёжи и поддерж-ки малого и среднего бизнеса. Хотя убедить удалось далеко не всех евродепутатов, в целом голосование 16 июля в Европарламенте закончилось благополучно для У. фон дер Ляйен: её кандидатура получила одобрение. Правда при очень незначительном большинстве голосов: 383 при необходимом минимуме 374; 327 евродепутатов голосовали против и 22 воздержались. Успех нового лидера Европейского союза, таким образом, представляется очень хрупким, а будущие отношения с новым парламентом - сложными.

\section{Выводы}

Было бы некорректно объяснять провал принципа назначения ведущего кандидата лишь действиями глав государств и правительств Евросоюза, которые на первое место поставили собственные национальные интересы, а не профессиональные качества будущих руководителей Евросоюза.

Торг между государствами-членами происходил каждый раз при распределении руководящих постов в ЕС, при этом профессионализм и политический опять не всегда играли главную роль в выборе кандидатуры: вспомним такие компромиссные, но бесцветные фигуры как Ж.-М. Баррозу или Х. ван Ромпей. Ж.-К. Юнкер как раз был скорее исключением из устоявшейся традиции.

На этот раз к убийству Spitzenkandidat приложили руку и европейские политические партии и фракции Европарламента, которые руководствовались своими собственными интересами, зачастую отличными от государственных.

В назначении главных руководителей Евросоюза - У. фон дер Ляйен и Ш. Мишеля победил франко-германский тандем, что доказывает выбор европейских политиков в сторону сохранения курса на продолжение интеграции.

Отказ от избрания ведущего кандидата мог бы привести к длительному межинституцио-

\footnotetext{
${ }^{1}$ Gray A., Barigazzi J., De La Baume M. Who killed the Spitzenkandidat? Politico. 07.07.2019. URL: https://www.poli tico.eu/article/who-killed-the-spitzenkandidat-european-parliament-election-2019-transition/ (дата обращения: 07.07. 2019).
} 
нальному противостоянию Евросовета и Европарламента, если бы У. фон дер Ляйен не смогла пройти утверждение в Европарламенте. На горизонте маячил очередной саммит и второй круг номинирования, что на длительное время отвлекло бы ЕС от решения насущных неотложных проблем. Поэтому очевидными оказались преимущества принципа Spitzenkandi$d a t$, который, возможно, вновь будет востребован после следующих выборов в Европарламент в 2024 г.

\section{Список литературы}

Потемкина О.Ю. Европейский парламент 2019: подготовка к выборам. Современная Европа, №4, 2018. С. 35-46.

Межевич Н.М. Новое руководство ЕС: опытные европейские «волки» действуют стаей. Валдай. Международный дискуссионный клуб. 2019. URL: http://ru.valdaiclub.com/a/high lights/ novoe-rukovodstvo-es/.

\section{References}

Potemkina O.Y. Evropejskij parlament 2019: podgotovka k vyboram. Sovremennaya Evropa, №4, 2018. S. 35-46.

Mezhevich N.M. Novoe rukovodstvo ES: opytnye evropejskie «volki» dejstvuyut staej. Valdaj. Mezhdunarodnyj diskussionnyj klub. 2019. URL: http://ru.valdaiclub.com/a/highlights/novoerukovodstvo-es/.

Gray A., Barigazzi J., De La Baume M. Who killed the Spitzenkandidat? Politico. 7 July, 2019 URL: https://www.politico.eu/article/who-killed-the-spitzenkandidat-european-parliament-election2019-transition/.

\section{Who killed Spitzenkandidat?}

Author. Olga Potemkina, Doctor of Sciences (Politics), Head of the Department of European Integration Studies, Institute of Europe, Russian Academy of Sciences. Address: 11-3, Mokhovaya str., Moscow, Russia, 125009. E-mail: olga_potemkina@mail.ru.

Abstract. The paper analyses the process of the new EU Commission President's nomination and election, as well as the other EU leaders. Based on results of the extraordinary EU summit (June 30 - July 1, 2019), which «buried» the Spitzenkandidaten system, as well as the debates in the European Parliament, the author concludes that not only the heads of state and government, but also European political parties and the MEPs are responsible for the failure of nominating a leading candidate.

Key words: leading candidate, summit, European Council, Commission, European Parliament, elections, transnational lists, European people's party, Party of European socialists, Osaka package.

DOI: http://dx.doi.org/10.15211/vestnikieran420193237 